KHAZANAH MULTIDISIPLIN

VOL 1 NO 22020

https://journal.uinsgd.ac.id/index.php/kl

\title{
ANALYSIS OF DEBT SHORT TERM AND RECEIVABLE TURNOVER ON THE PROFITABILITY OF MANUFACTURING COMPANIES
}

\author{
Dian Efriyenty \\ Program Studi Akuntansi, Fakultas Ilmu Sosial dan Humanioura, \\ Universitas Putera Batam \\ Email: dianefriyenty@gmail.com
}

Diterima : 7 November 2020, Revisi : 20 November 2020 Disetujui : 25 November 2020

\begin{abstract}
Based on the survey results for the last 3 years, data on food companies and the minimum turnover of accounts receivable and debt has increased and this has an impact on taking profits in the form of assets. These things can have an impact on the investment invested in shareholders. The purpose of this study is to assess the effect of short-term debt and accounts receivable turnover on asset returns. The samples in this study were 8 companies in the 2015-2019 period. The results of t-test analysis partially show that short-term debt does not have a significant effect on profitability, receivables turnover has a significant effect on profitability.
\end{abstract}

Keywords: short-term debt, accounts receivable turnover, profitability

\begin{abstract}
ABSTRAK
Berdasarkan hasil survey 3 tahun terakhir data perusahaan makanan dan minimum perputaran piutang dan utang semakin naik serta hal ini nnatinya sangat berdampak pada pengambilan keuntungan dalam bentuk asset. Hal-hal tersebut dapat berdampak kepada investasi yang ditanamkan kepada pemegang saham. Tujuan penelitian ini untuk menilai pengaruh hutang jangka pendek dan perputaran piutang terhadap pengembalian asset. Sampel dalam penelitian ini sebanyak 8 perusahaan pada periode 2015-2019. Hasil analisis uji-t secara parsial menunjukkan bahwa hutang jangka pendek tidak berpengaruh signifikan terhadap profitabilitas, perputaran piutang berpengaruh signifikan terhadap profitabilitas.
\end{abstract}

Kata kunci: hutang jangka pendek, perputaran piutang, profitabilitas

\section{PENDAHULUAN}

Semakin berkembangnya dunia usaha perusahaan selalu mengharapkan semakin maju tingkat perekonomian suatu usahanya (Widiasmoro, 2017). 
KHAZANAH MULTIDISIPLIN

VOL 1 NO 22020

https://journal.uinsgd.ac.id/index.php/kl

Piutang yang tinggi akan berdampak pada profit perusahaan begitu halnya utang jangka pendek dan utang jangka Panjang yang tinggi maka akan mengurangi pengembalian investasi juga untuk pemegang saham. Berdasarkan survey semakin tinggi perputaran piutang dan perputaran sehingga berdampak pada penjualan kredit serta piutang yang diinvestasikan.

Berdasarkan data keuangan bahwa piutang dari tahun 2015 yaitu 7,56 mencapai 6,65 ditahun 2016 kemudian naik ditahun 2017 mencapai 8,59. Begitu halnya untuk hutang jangka pendek naik selama 3 tahun terakhir 4,33 ditahun 2015 naik ditahun 2016 menjadi 6,78, kemudian tahun 2017 naik lagi 8,90. Meningkatnya piutang dan hutang jangka pendek, maka akan semakin sedikit keuntungan yang dihasilkan oleh usaha.

\section{KAJIAN PUSTAKA}

\section{Profitabilitas}

Kemampuan perusahaan untuk menghasilkan laba (Kasmir, 2012:196).

$$
\text { ROA }=\frac{\text { Laba Bersih }}{\text { Total Aset }}
$$

\section{Hutang Jangka Pendek}

Suatu kegiatan usaha jangka pendek yang habis masa jatuh temponya harus dibayar oleh usaha (Fahmi, 2017:83).

\section{Piutang}

Penjualan yang dilakukan secara kredit untuk menagih kepada pelanggannya.sebaliknya profitabilitas yang rendah akan cenderung menurunkan nilai perusahaan dalam jangka pendek. Hal ini bisa saja 
KHAZANAH MULTIDISIPLIN

VOL 1 NO 22020

https://journal.uinsgd.ac.id/index.php/kl

dipengaruhi oleh tingkat profitabilitas setiap tahunnya, semakin baik rasio profitabilitas maka semakin baik pula perolehan keuntungan perusahaan (Widiasmoro, 2017). Perusahaan yang menggunakan hutang untuk mendanai perusahaa dan tidak mampu melunasi hutangnya maka akan terancam likuiditasnya. Perusahaan akan berhutang smpai pada tingkat hutang tertentu, perusahaan-perusahaan yang profitabilitasnya tinggi tentu akan berusaha mengurangi hutangnya dengan cara meningkatkan penjualan.

\section{Perputaran Piutang}

Untuk mengukur sejauh mana pelanggan melunasi piutangnya (Kasmir, 2012:176).

\section{Penelitian Terdahulu}

Research (Lubis, 2017) hutang jangka pendek berdampak pada profitabilitas unit usaha. Begitu halnya dengan (Putu Putri Wirasari \& Ratna Sari, 2016) berdampak pada profitabilitas usaha. Hipotesis dalam research ini diantaranya:

H1: Debt Short term berpengaruh terhadap pengembalian asset

H2: Account receivable turnover berpengaruh terhadap pengembalian asset

H3: Debt short term and account receivable turnover terhadap pengembalian asset

\section{METODE PENELITIAN}

Populasi dalam penelitian ini adalah perusahaan manufaktur yang terdaftar di Bursa Efek Indonesia sub sektor makanan dan minuman selama tahun periode 2015-2019 yang berjumlah 18 perusahaan.

Metode sampel menggunakan purposive sampling dari 8 perusahaan yang memenuhi. Analisa data dengan uji asumsi klasik dan regresi berganda. 
KHAZANAH MULTIDISIPLIN

VOL 1 NO 22020

https://journal.uinsgd.ac.id/index.php/kl

\section{HASIL DAN PEMBAHASAN}

\section{Hasil Uji t}

Adapun hasil uji t secara parsial dalam penelitian ini :

\begin{tabular}{|c|c|c|c|c|c|}
\hline \multirow{2}{*}{ Model } & \multicolumn{2}{|c|}{$\begin{array}{c}\text { Unstandardized } \\
\text { Coefficients }\end{array}$} & \multirow{2}{*}{$\begin{array}{c}\text { Standardized } \\
\text { Coefficients } \\
\text { Beta }\end{array}$} & \multirow{2}{*}{$\mathbf{T}$} & \multirow{2}{*}{ Sig. } \\
\hline & B & $\begin{array}{l}\text { Std. } \\
\text { Error }\end{array}$ & & & \\
\hline (Constant) & 0.023 & 0.014 & & 1.68 & 0.102 \\
\hline $\begin{array}{l}\text { Hutang Janglza } \\
\text { Pendek }\end{array}$ & $\begin{array}{r}-3 \cdot 77 \mathbf{E}- \\
16\end{array}$ & $\mathbf{O}$ & -0.01 & 0.082 & 0.935 \\
\hline Perputaran Piutaag & $\begin{array}{r}-1.14 \mathrm{E}- \\
05\end{array}$ & $\mathbf{O}$ & -0.159 & $1.274^{-}$ & 0.211 \\
\hline
\end{tabular}

Berdasarkan hasil outpot receivable turnover tidak berpengaruh signifikan terhadap pengembalian keuntungan, tetapi perputaran piutang berpengaruh dikarenakan nilai signfikannya dibawah 0,05 .

\section{Uji F}

Berdasarkan hasil olahan data uji f yaitu:

Tabel 7. Uji F

\begin{tabular}{|c|c|c|c|c|c|c|}
\hline Model & & $\begin{array}{l}\text { Sum of } \\
\text { Squares }\end{array}$ & Df & $\begin{array}{c}\text { Mean } \\
\text { Square }\end{array}$ & $\mathrm{F}$ & Sig. \\
\hline & Regression & 0.03 & 3 & 0.01 & 10.202 & $.000^{b}$ \\
\hline & Residual & 0.036 & 36 & 0.001 & & \\
\hline & Total & 0.066 & 39 & & & \\
\hline
\end{tabular}

a. Dependent Variable: Profitabilitas (ROA)

Hasil menyatakan secara bersamaan berpengaruh terahadappengembalian keuntungan dalam bentuk asset.

\section{Debt Short term berpengaruh terhadap pengembalian asset}

Hasil uji t bahwa debt short term berdampak pada pengembalian asset. Hal ini dikarenakan jika hutang tinggi maka akan semakin tinggi resiko kewajiban perusahaan dalam melunasi utang jangka pendeknya begitu juga kebalikannya. Penelitian ini konsisten dengan (Lubis, 2017) yang menyatakan short term berdampak pada pengembalian keuntungan.

Account receivable turnover berpengaruh terhadap 
KHAZANAH MULTIDISIPLIN

VOL 1 NO 22020

https://journal.uinsgd.ac.id/index.php/kl

\section{pengembalian asset}

Berdasarkan hasil perputaran receivable turnover berpengaruh signfikan terhadap pengembalian asset hal ini dikarenakan semakin tinggi piutang maka akan semakin berdampak penurunan pegembalian investasi dari pemegang saham. Hasil penelitian ini sejalan dengan (Ruhmana \& Ardini, 2017) bahwa receivable turnover berdampak pada pengembalian asset.

\section{Debt short term and account receivable turnover terhadap pengembalian asset}

Berdasarkan hasil uji $\mathrm{F}$ bahwa debt short term and receivable turnover berdampak pada pengembalian asset. Seberapa dampak perusahaan dalam melunasi utang jangka pendek dan perputaran piutang, sehingga akan berdampak pada keuntungan perusahaan. Hal ini didukung dari (Nengsy, 2015) mengatakan receivable turnover has feedback as an impact return.

\section{SIMPULAN}

Berdasarkan simpulan dari hasil penelitian ini dinyatakan :

1. Short term debt turnover no significant effect on assets.

2. Accounts receivable turnover affects asset returns.

3. Short term debt and accounts receivable turnover have an impact on asset return.

\section{DAFTAR PUSTAKA}

Fahmi, I. (2017). Analisis laporan keuangan. Bandung: Alfabeta.

Hery. (2011). Akuntansi Aktiva, Utang, dan Modal. Yogyakarta: Gava Media.

Kasmir. (2012). Analisis Laporan Keuangan (Lima). Jakarta: Rajagrafindo Persada.

Lubis, N. K. (2017). Jurnal penelitian ekonomi akuntansi (jensi), vol. 1, no.

2, desember 2017. Penelitian Ekonomi Akuntansi, 1(Kualitas Pelaporan Keuangan), 1-13.

Nengsy, H. (2015). Pengaruh perputaran modal kerja dan perputaran 
KHAZANAH MULTIDISIPLIN

VOL 1 NO 22020

https://journal.uinsgd.ac.id/index.php/kl

piutang terhadap profitabilitas pada perusahaan manufaktur yang terdaftar di bursa efek indonesia, 4, 1-11.

Putu Putri Wirasari, W., \& Ratna Sari, M. M. (2016). Pengaruh Perputaran Modal Kerja, Perputaran Kas, Perputaran Piutang, dan Pertumbuhan Koperasi terhadap Profitabilitas. E-Jurnal Akuntansi Universitas Udayana, $17(2)$, 885-912. https://doi.org/10.1152/ajpregu.00746.2005 